\title{
Volcanic Hazards in the Pacific U.S. Territories
}

The Commonwealth of the
Northern Mariana Islands,
Guam, and American Samoa
lie along the western side of
the famed Pacific Ring of
Fire. Here, the processes of
active island and submarine
volcanoes produce activity
both underwater and in the
atmosphere that poses potential
hazards to the daily lives of
residents and travelers. Since
2000, CNMI volcanoes have
erupted six times, and one sub-
marine volcano has been active
in American Samoa.

The Commonwealth of the Northern Mariana Islands (CNMI) is home to 9 volcanic islands and about 60 submarine volcanoes (also called seamounts), some of which are within the Mariana Trench Marine National Monument. Of these, six island volcanoes and six submarine volcanoes have had confirmed eruptions since the 1800 s. Eruptions pose potential hazards to aircraft, ocean traffic, and local and regional populations in the CNMI and Guam. The U.S. Geological Survey (USGS) regularly monitors the island volcanoes for activity with groundand satellite-based instruments when data are available. Submarine volcanoes are more difficult to monitor, but large eruptions can still be detected with the same instruments.

In American Samoa, the three populated volcanic islands of Tutuila, Ofu-Olosega, and $\mathrm{Ta}^{\prime} \overline{\mathrm{u}}$ have largely been inactive since the 1800 s. The most recent volcanic activity has been from the submarine volcano Vailulu' $u$, located in the Marine Sanctuary of American Samoa and adjacent to the Rose Atoll Marine National Monument. The USGS does not currently monitor volcanoes in American Samoa with ground-based instruments.

\section{Island Volcanic Hazards}

CNMI volcanoes erupt on average once every three to five years but also occasionally produce noneruptive volcanic activity, such as earthquakes and minor releases of gas. Although Farallon de Pajaros used to be called the 'Lighthouse of the western Pacific' because of its relatively frequent historical eruptions, only two volcanoes (Pagan and Anatahan) have erupted since 2000. However, volcanoes that have not erupted historically may still reawaken. For example, Anatahan's 2003 eruption was its first in at least a few hundred years.

Island volcanoes pose a direct threat to people living on them. In the past, people have been temporarily evacuated because of volcanic activity. Inhabitants of Pagan Island were evacuated during its 1981 eruption, which persisted through 1985. In 1990, residents of Anatahan Island were evacuated in anticipation of an eruption after an increase in earthquake activity. Habitation of the active island volcanoes is usually intermittent, although there is demand from some citizens to reestablish permanent residence at their ancestral homes.

[Aerial photo of a gas plume from Mount Pagan during a period of volcanic activity in May 2013. U.S. Geological Survey photograph by John Lyons.

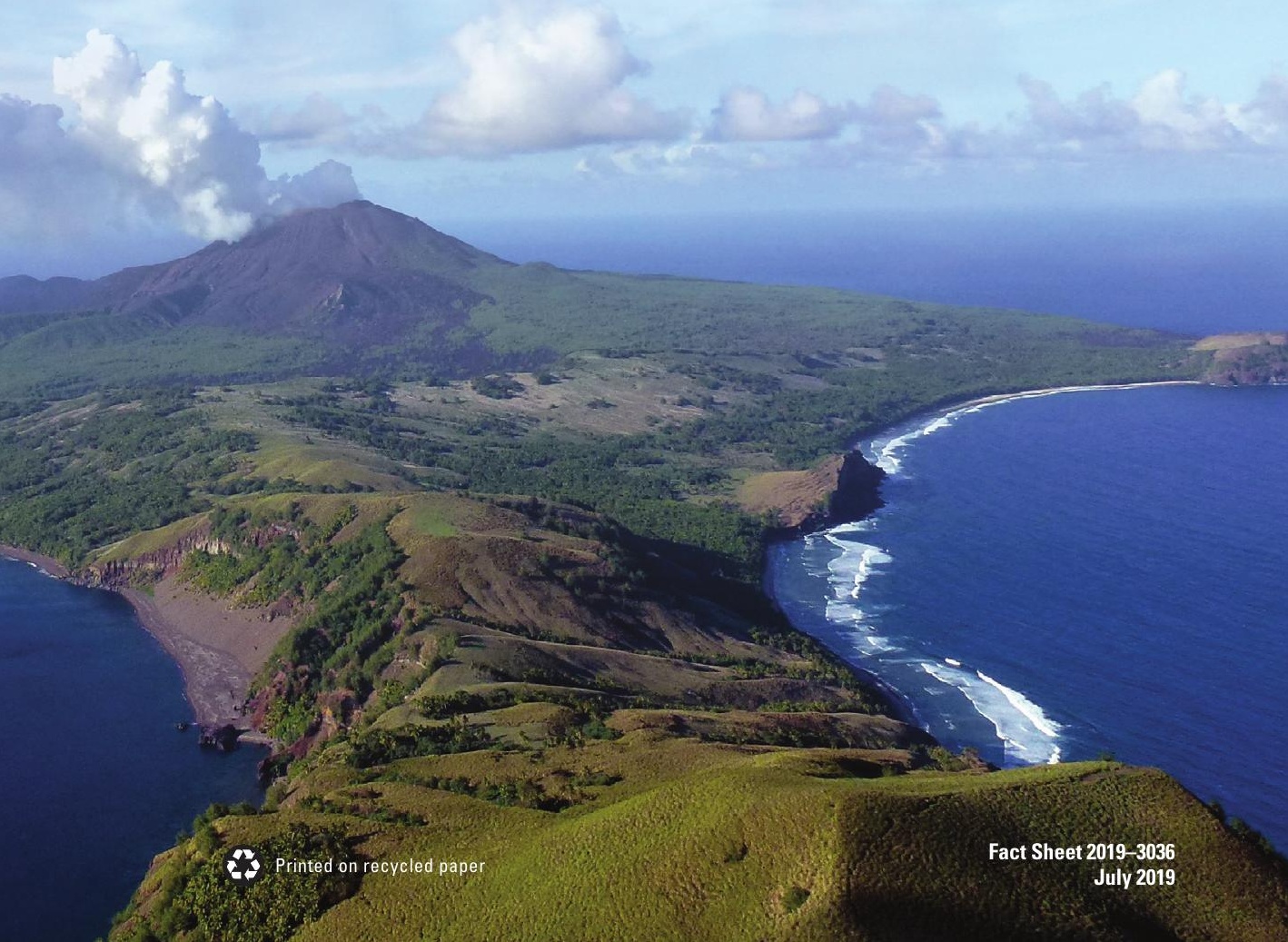


Uninhabited volcanoes can still pose a threat to society. Eruptions from both island and submarine volcanoes can be hazardous to aircraft and nearby ships and fishing boats. Explosive eruptions can send ash plumes high into the atmosphere, creating a hazard to aircraft and possibly depositing ash on the populated islands and international airports of Guam and Saipan. Gases and ash expelled from CNMI volcanoes have been known to reach populated areas as far as the Philippines, leading to poor air quality and health issues. Landslides can also occur during or after volcanic eruptions. Though landslides are typically only a hazard to people living near them, under the right conditions they can potentially cause tsunamis that affect a wider area.

In contrast to the CNMI, the island volcanoes of American Samoa are quite old with their activity occurring more than 10,000 years ago. However, volcanic activity offshore the twin volcanic island of Ofu-Olosega in 1866 suggests that the volcanoes may not be completely extinct.

\section{Submarine Volcanic Hazards}

Most CNMI volcanoes are hidden below the surface of the sea. About a third of these submarine volcanoes host active hydrothermal systems, thriving biological communities, and other natural wonders, such as Daikoku seamount with its bubbling vents and craters filled with molten sulfur. The heat that drives these hydrothermal systems comes from magma beneath the surface, which means the host volcanoes are also capable of erupting.

The products of many submarine eruptions stay underwater and out of sight, making it difficult to know how active these volcanoes really are. Thus, new discoveries of active volcanism are still being made today. A National Oceanic and Atmospheric Administration (NOAA) research expedition to map hydrothermal activity in 2003 discovered an eruption underway at NW Rota-1 seamount, at a depth of 1,700 feet ( 517 meters). Later expeditions confirmed that this eruption continued until early 2010. Without any activity reaching the sea surface, this eruption would have gone undetected if not for the timely research expedition.

Submarine eruptions can sometimes breach the sea surface and become more hazardous. When South Sarigan seamount erupted in 2010 from over 500 feet (150 meters) below sea level, it produced a steam and ash plume that reached over 39,000 feet (12 kilometers) into the atmosphere and eventually passed over Saipan and Guam. Fishermen and other marine vessels have also reported underwater explosions, discolored water, or suddenly being surrounded by bubbling water at various places along the island arc. Such activity is commonly associated with submarine eruptions.

Submarine volcanic activity can also occur at locations other than seamounts. The Mariana back-arc spreading center, located west of the Mariana Island chain in much deeper water, is geologically active. Similar to seamounts, magma underneath

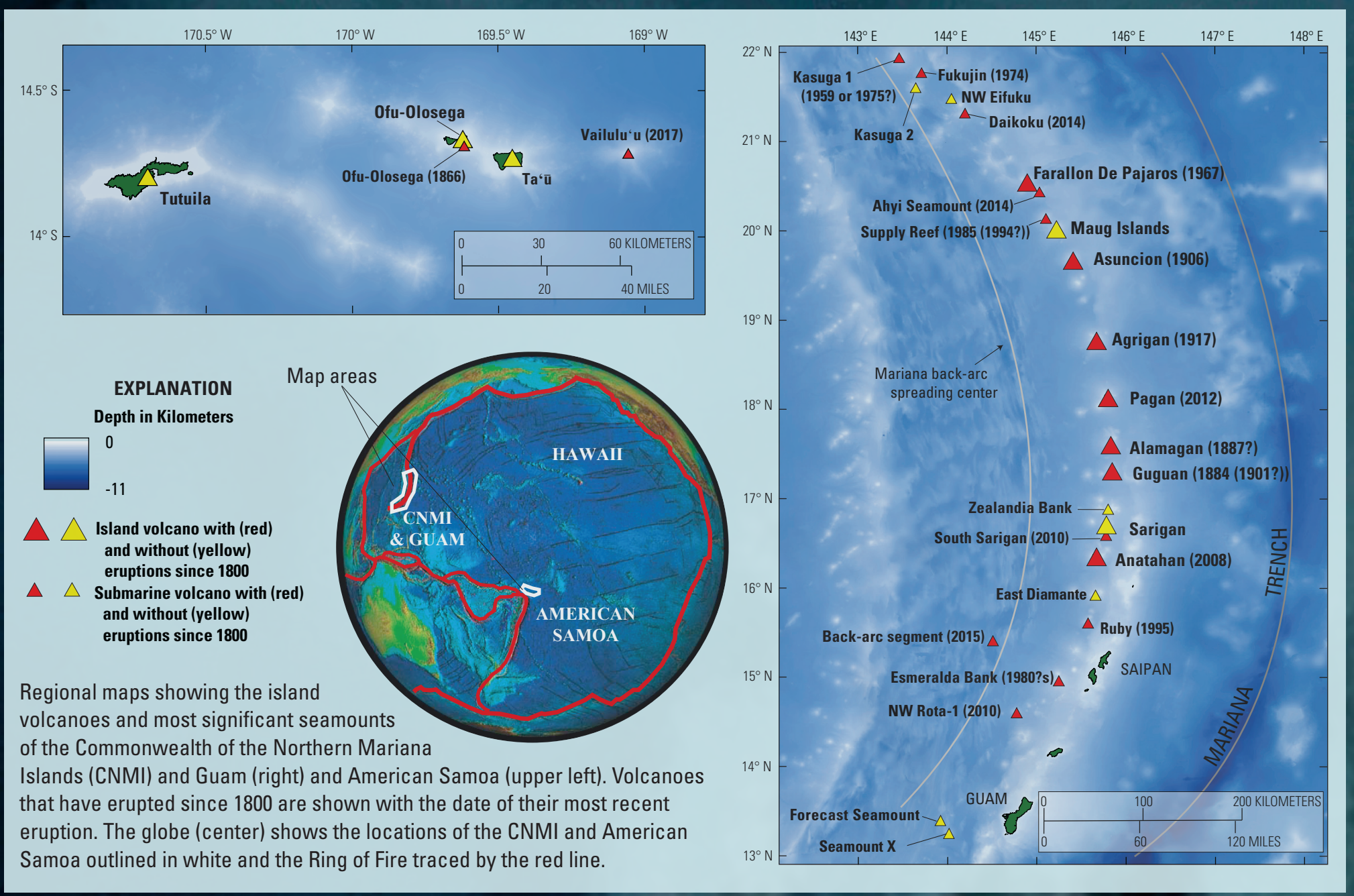


the sea floor generates widespread hydrothermal activity and occasional submarine lava flows. Some island volcanoes have submerged components (cones, vents, or fissures) that can also produce volcanic activity.

In American Samoa, Vailulu'u Seamount is currently the most active of all the volcanoes, although it was only discovered in 1975. It is likely the source of geophysical activity detected from the region in 1973, 1995, and 2000. A new lava cone grew within the summit crater of Vailulu' $u$ between surveys conducted in 2001, 2005, and 2012, and follow-up NOAA expeditions in 2006 and 2017 revealed that the cone continued to grow. The 2017 expedition also discovered a plume of bubbles produced by hydrothermal activity rising from the summit crater's floor.

\section{Current Monitoring and Eruption Response}

The USGS, in coordination with the CNMI Office of Homeland Security \& Emergency Management (HSEM), has been monitoring CNMI volcanoes since 1981. Scientists check ground-based and satellite data daily for signs of volcanic unrest. Seismic monitoring can detect activity, such as earthquakes and tremors, that may precede or accompany eruptions. Complementary to seismic waves in the earth, infrasound monitoring can detect atmospheric sound waves with a pitch lower than human hearing that are produced during explosive eruptions and by other near-surface activity.

The modern ground-based monitoring network began in response to the 2003 Anatahan eruption. It has since expanded to include cameras and seismic and infrasound instruments on Saipan Island and three volcanic islands to the north (Anatahan Island, Sarigan Island, and Pagan Island). The volcanic island stations are difficult to maintain and are operated when logistical and cost constraints allow. The seismic and infrasound network operating on Saipan has the ability to detect distant volcanic eruptions but offers little forecasting capability that might provide advance warning. Saipan's great distance from the active volcanoes means that only the strongest activity will be detected by this network.

Satellite remote sensing is an additional tool used to detect and track volcanic activity in

Photograph of NW Rota-1 erupting in 2006 taken during an expedition with a remotely operated vehicle (NOAAPMEL-Earth-0cean Interactions Program). NW Rota-1 is a 1,700-foot-deep submarine volcano, which erupted regularly from 2003-2010. This picture shows an eruption plume emanating from the vent during one of many explosions. Image courtesy of the National Oceanic and Atmospheric Administration (NOAA) Pacific Marine Environmental Laboratory (PMEL) and the Woods Hole Oceanographic Institution. the CNMI and Guam, some of which might not be detectable by ground-based instruments. Several international satellites collect images minutes to days apart, offering frequent views of the volcanoes before, during, and after eruptions; however, imagery can sometimes be obscured by clouds or not timed correctly to capture eruptions in detail. One example of satellite monitoring is the detection of abnormally hot areas that could be eruption precursors, such as magmatic gas and steam emissions, or signs of eruption, such as lava and pyroclastic flows. When an eruption is underway, satellite monitoring is used to detect and track ash and gas plumes over time to learn more about how the eruption is progressing and to better assess potential impacts to society.

Submarine volcanoes are much more difficult to monitor than island volcanoes. The local CNMI seismic and infrasound network can detect strong submarine explosions, earthquakes, and eruptions that breach the sea surface. Eruptive products, such as discolored water, steam and ash plumes, and large 


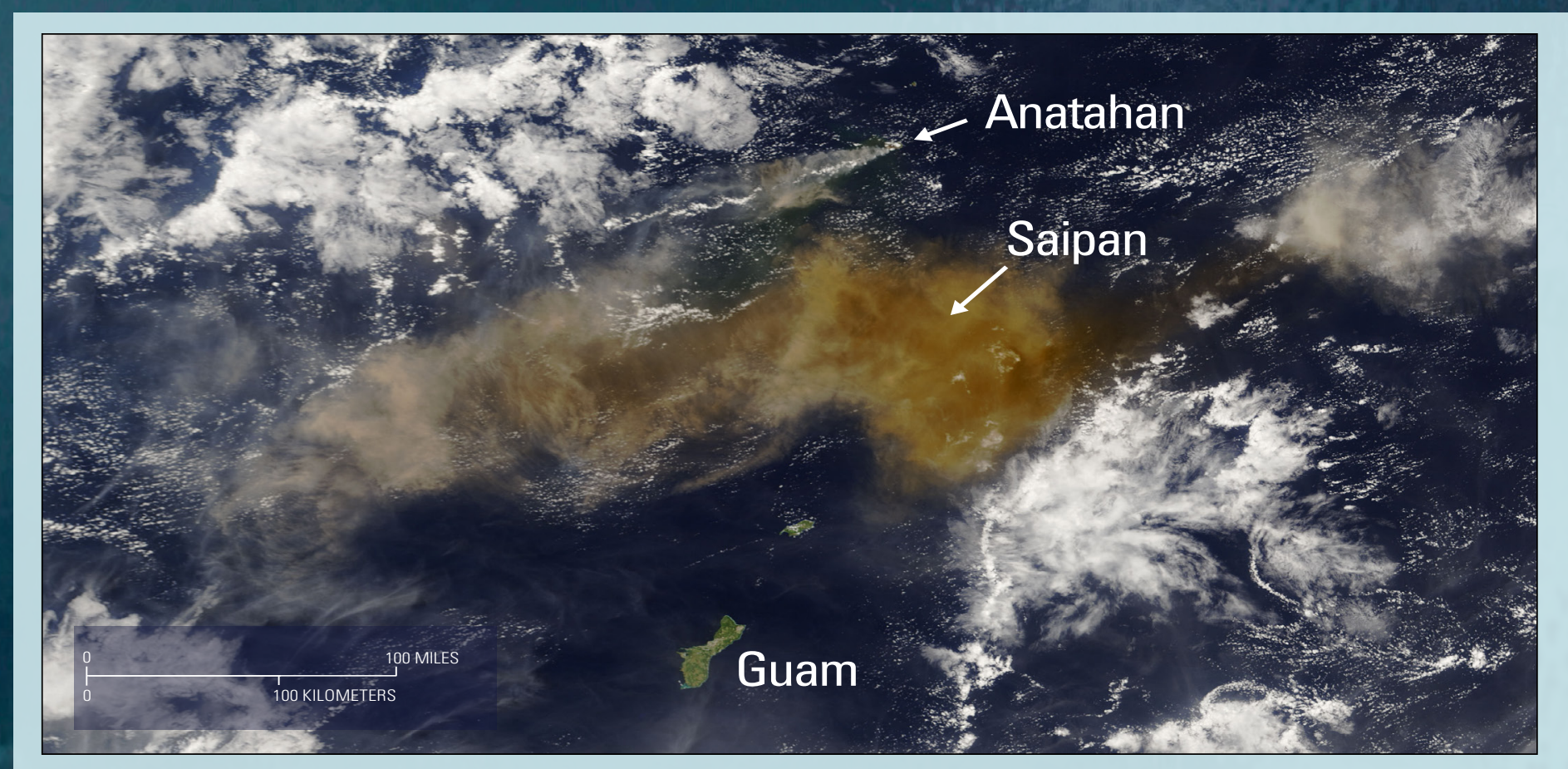

Satellite image of an ash plume from the April 6, 2005, Anatahan Island eruption that rose to about 49,000 feet (15 kilometers). The image was captured about 8 hours after the eruption began and shows the ash plume covering Saipan Island, demonstrating the far-reaching hazards of volcanoes. Image from the National Aeronautics and Space Administration Moderate Resolution Imaging Spectroradiometer Rapid Response image gallery.

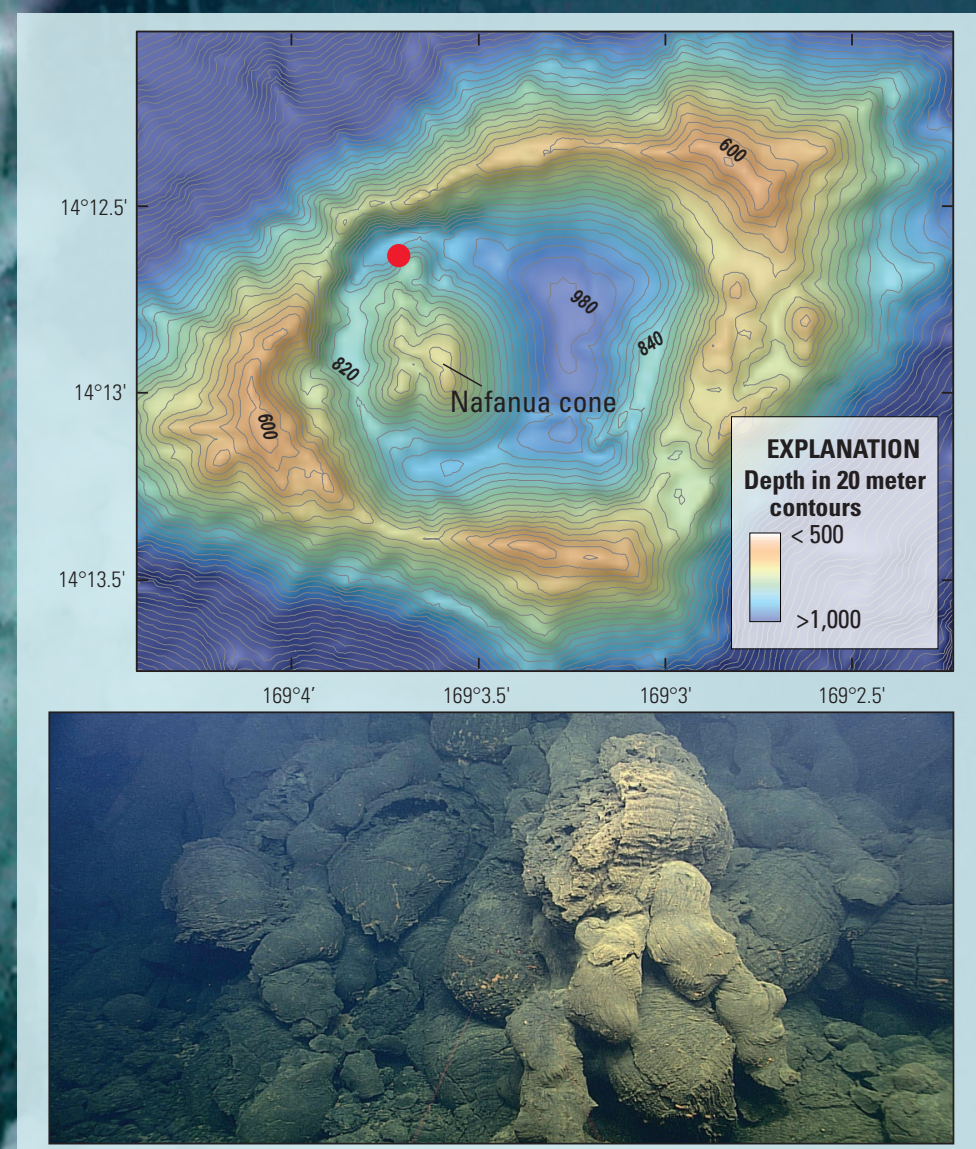

Bathymetric map (above) of Vailulu'u seamount courtesy of the National Oceanic and Atmospheric Administration (NOAA) Pacific Marine Environmental Lab. The red dot on the map marks the approximate location of the photograph shown below. Photograph of pillow structures (below) that formed from the rapid cooling of lava erupted underwater on Nafanua cone (above). Photograph courtesy of the NOAA Office of Ocean Exploration and Research. pumice rafts, can sometimes be identified in satellite images. Regional hydrophones (underwater microphones) can also aid in monitoring these volcanoes. However, the USGS does not currently operate any hydrophones that provide real-time data and relies on other national and international organizations for this monitoring data.

If an eruption of a CNMI volcano is detected, the USGS issues alerts, including Volcanic Activity Notices and Volcanic Observatory Notices for Aviation. These alerts are distributed via the USGS Volcanic Notification Service. The USGS volcano observatories share responsibility for CNMI volcano monitoring, which is primarily done remotely.

Warnings and restrictions related to eruptions are issued by various agencies. The Federal Aviation Administration may issue flight restrictions if an ash plume is present or expected, whereas the National Weather Service and NOAA may issue warnings about air quality and potential marine hazards, including tsunamis. The Washington D.C. Volcanic Ash Advisory Center (VAAC), operated by the National Weather Service, issues ashrelated notices for CNMI airspace. The CNMI HSEM would also be involved in response activities.

The USGS does not currently perform regular volcano monitoring of American Samoa or operate ground-based instruments there. Nearby instruments from regional and global seismic, infrasound, and hydrophone networks may be able to detect strong éruptions or volcanic earthquakes. Satellites may detect large ash plumes, lava flows, or other major surficial activity that occurs. If any substantial volcanic activity does occur, similar procedures to those in the CNMI would be followed, and the American Samoa Territorial Emergency Management Coordinating Office would be involved. American Samoa is located in the region covered by the VAAC in Wellington, operated by the Meteorological Service of New Zealand. 


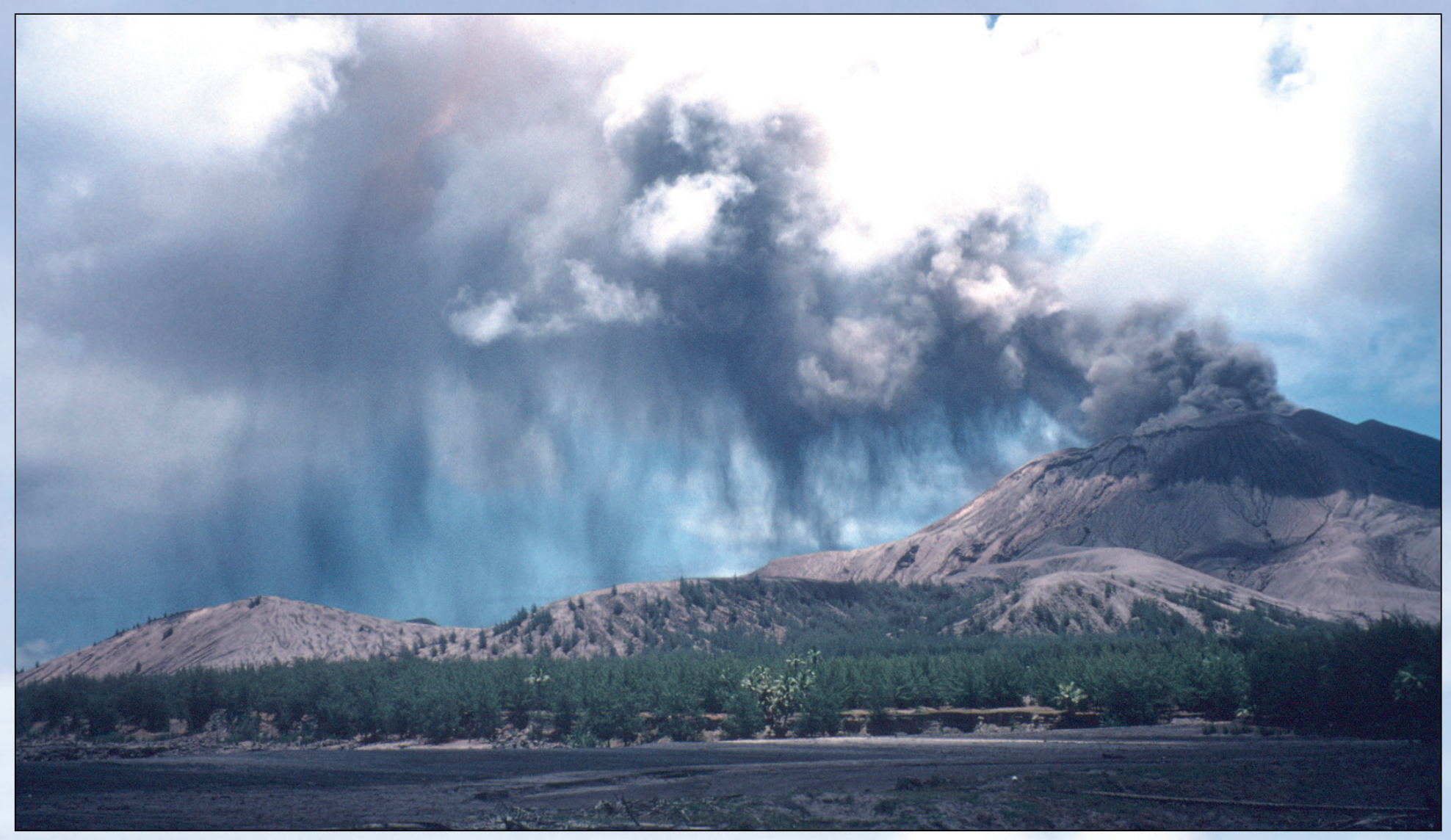

Photograph of an ash plume produced by the May 1994 eruption of Mount Pagan-one of the most active volcanoes of the Commonwealth of the Northern Mariana Islands in recent history. U.S. Geological Survey photograph by Frank Trusdell.

\section{Finding the Source of a Submarine Eruption}

During a daily Commonwealth of the Northern Mariana Islands (CNMI) data check in April 2014, U.S. Geological Survey seismologists noticed unusual signals coming from somewhere north of Pagan Island. These were hydroacoustic signals - the recordings of sound waves that travel through the ocean but are strong enough to be recorded on land. Meanwhile, scuba divers from a National Oceanic and Atmospheric Administration (NOAA) research expedition near Farallon de Pajaros reported hearing underwater explosions. A particularly strong shock wave reverberated through the ship's hull, leading the crew to believe that something had happened to the ship until the divers relayed their observations. Hydroacoustic signals have been detected from submarine volcanoes in the region between the Maug Islands and Farallon de Pajaros several times since the 1960 s, usually by hydrophones over 1,400 miles (2,250 kilometers) away in the central Pacific Ocean. These hydrophones showed that the 2014 signals came from the same region, but confirming which volcano was erupting required more evidence. A NOAA hydrothermal plume survey and bathymetric mapping at Ahyi Seamount, completed after the eruption ended two weeks later in May 2014, confirmed that it was the source. The bathymetry maps showed a new crater had formed near the summit (now 246 feet [ 75 meters] deep) that was the result of several thousand explosions. The eruption also left a large landslide chute on the southeast side of the seamount.

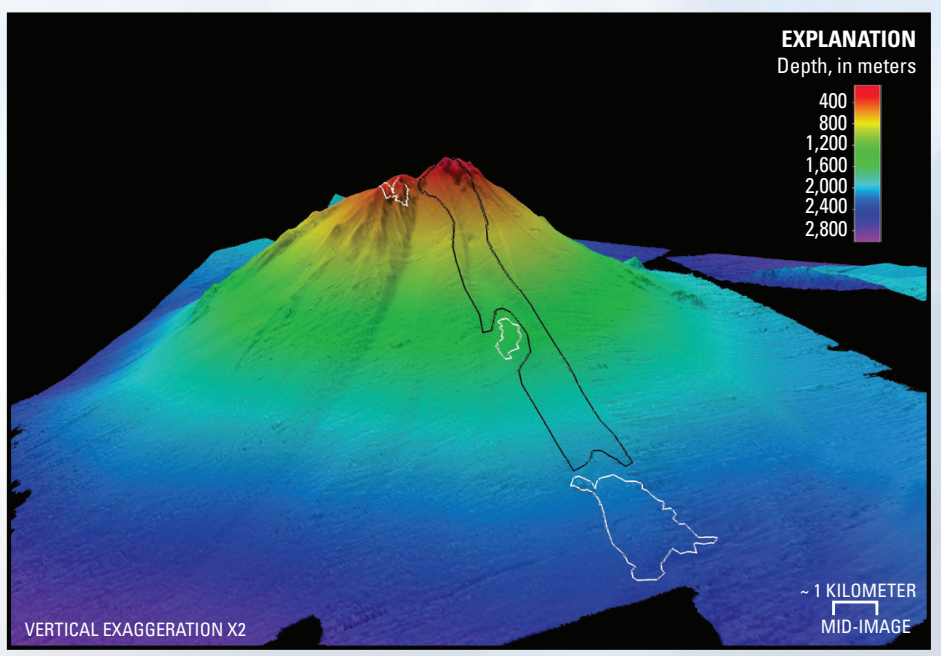

Oblique three-dimensional view of Ahyi Seamount, which is located near Farallon de Pajaros and erupted in 2014. This view, looking to the NNW $\left(348^{\circ}\right)$, shows 2014 bathymetry where areas that experienced a depth change between 2003 and 2014 are outlined in black (negative changes) or white (positive changes). These changes reveal a landslide that removed material in the long black outlined area and deposited it in the lower white outlined areas. The black outlined area also includes a newly formed crater at the former summit. The areas of positive depth change near the summit are the result of poor quality data. Image courtesy of Susan Merle (NOAA Pacific Marine Environmental Laboratory). 


\section{The First Historical Eruption of Anatahan}

In the early morning of May 10,2003, scientists on a research ship working on the volcanic islands in the Commonwealth of the Northern Mariana Islands (CNMI) noticed a lightning storm in the distance. By dawn, they were able to spot the source - an eruption of Anatahan. Fortuitously, the scientists' mission was to install seismographs in the CNMI, one of which had been set up on Anatahan Island only three days before the eruption began. The eruption came unexpectedly with no precursors recorded or observed at the time. However, when the seismograph was retrieved, a few hours of precursory activity were identified in the data. Previous earthquake swarms in 1990 and 1993 led to evacuation of the small village on the island, but neither was followed by an eruption. In 2003, Anatahan continued to erupt through June, sending plumes of ash and gas as high as 39,000 feet (12 kilometers) into the atmosphere and building a lava dome within its crater. The U.S. Geological Survey and CNMI Office of Homeland Security \& Emergency Management launched a response effort, making periodic survey flights of the activity and installing additional ground-based monitoring equipment. Anatahan ultimately remained active and erupted periodically until 2009, although major explosive eruptions ended in 2005. At times, plumes of ash and $\mathrm{SO}_{2}$ gas reached the islands of Saipan and Guam, resulting in light ash fall and air quality issues on populated islands. Low concentrations of ash and gas were even detected as far away as the Philippine Islands. During a period of volcanic haze in August 2005, an airplane leaving Saipan had engine problems shortly after takeoff. The plane was able to land safely, but the story is a good reminder that volcanic hazards can extend far from the volcano itself.

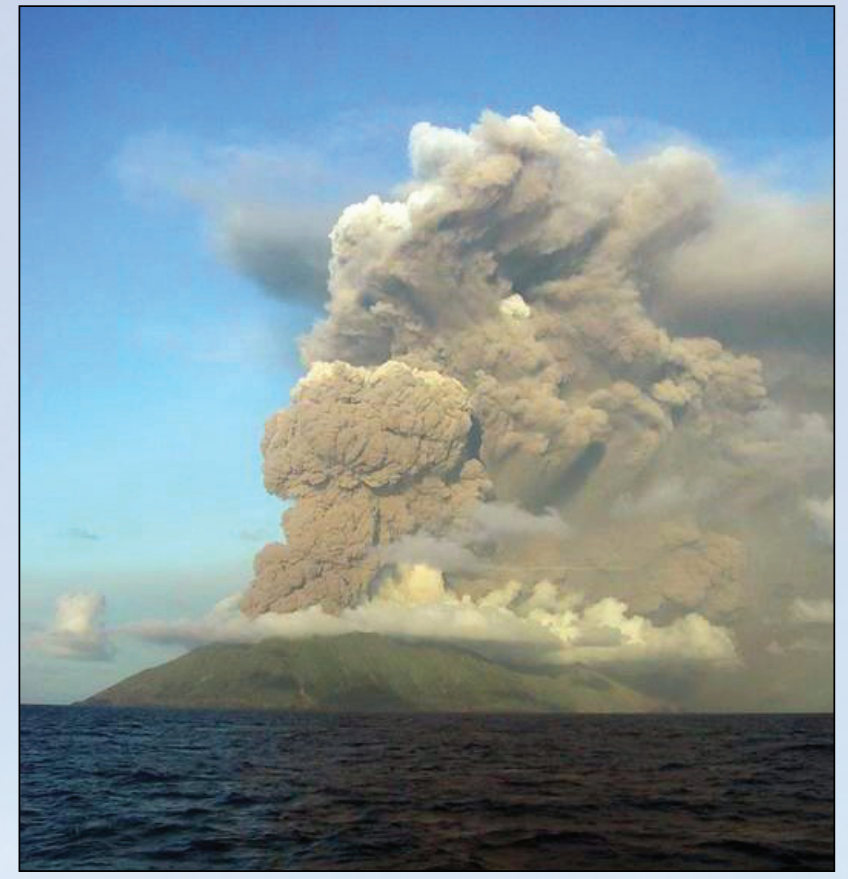

The first historical eruption of Anatahan occurred on May 10,2003 . The eruption plume, comprising dark ash and white steam, ultimately reached an altitude of 39,000 feet (12 kilometers). Major explosive activity continued until 2005 with minor activity lasting until 2009. Photograph by Brian Shiro.

\section{What You Can Do to Be Prepared}

The time between the earliest indications of volcanic activity and the start of an eruption can range from minutes to months. The USGS Volcano Hazards Program and its monitoring partners work to detect the earliest signals of volcanic activity to forewarn communities at risk and provide time for officials to activate emergency response plans and mitigation measures that can save lives and protect property. Because of the sparse volcano monitoring infrastructure in the CNMI and American Samoa, the USGS currently has limited ability to detect and characterize volcanic activity in these regions.

The best preparation is to be aware of potential hazards and current volcanic activity. Follow local recommendations, even in times of no activity, to ensure your households and businesses are prepared in the case of an emergency. This includes having an emergency plan and an emergency kit that can sustain you for as long as two weeks. When a volcano is erupting, read issued notifications and follow the given guidance. You can consult local emergency management agencies for more information:

Commonwealth of the Northern Mariana Islands

Office of Homeland Security \& Emergency Management, Saipan

Telephone: 1-670-237-8000,

Website: http://www.cnmihsem.gov.mp/

Guam Homeland Security Office of Civil Defense

Telephone: 671-475-9600,

Website: https://www.ghs.guam.gov/

American Samoa, Territorial Emergency Management

Coordinating Office, Pago Pago,

Telephone: (011) 684-699-6415

\section{Learn more about volcanic hazards at:}

USGS volcanic ash website:

https://volcanoes.usgs.gov/volcanic_ash/

The Interagency Vog Information dashboard: https://vog.ivhhn.org/

USGS Volcano Hazards Program education webpages: https:/volcanoes.usgs.gov/vhp/education.html

\section{For more information:}

USGS Northern Mariana Islands volcanoes website: https://volcanoes.usgs.gov/nmi/

NOAA Marianas website:

https://www.pmel.noaa.gov/eoi/marianas_site.html

2017 NOAA visit to Vailulu'u:

http:/oceanexplorer.noaa.gov/okeanos/explorations/ex1702/logs/ feb22/

Sign up for volcanic activity alerts here:

USGS Volcano Notification Service https://volcanoes.usgs.gov/vns2//subscribe

\section{Gabrielle Tepp and Brian Shiro, U.S. Geological Survey,} and William Chadwick, NOAA

Edited by Phil Frederick

Graphic design and layout by Kimber Petersen 